\title{
PENDAMPINGAN GURU PEMBINA OSN MATEMATIKA SMP NEGERI 1 JETIS BESERTA SEKOLAH IMBASNYA
}

\author{
Arta Ekayanti ${ }^{1}$, Senja Putri Merona ${ }^{2}$, Uki Suhendar ${ }^{3}$ \\ ${ }^{1,2,3)}$ Program Studi Pendidikan Matematika, FKIP, Universitas Muhammadiyah Ponorogo \\ e-mail: arta_ekayanti@ymail.com
}

\begin{abstract}
Abstrak
Kegiatan OSN merupakan kegiatan tahunan yang diselenggarakan oleh Direktorat Pembinaan SMA, Direktorat Pendidikan Dasar dan Menengah, Kementrian Pendidikan dan Kebudayaan, yang merupakan kompetisi yang menjadi perhatian khusus dari sekolah. Dimana sekolah-sekolah akan mengirimkan peserta didik terbaiknya khususnya dalam bidang Sains. Tujuan dari kegiatan pendampingan ini untuk memberikan penguatan materi kebutuhan OSN Matematika bagi para pembina OSN Matematika. Hal ini dilakukan agar lebih optimal dalam mendampingi serta membina peserta didiknya. Metode kegiatan ini dilakukan melalui beberapa tahapan meliputi, tahap awal, tahap persiapan dan tahap pelaksanaan. Tahap awal berupa analisis kebutuhan, tahap persiapan berupa penyiapan instrumen sedangkan tahap pelaksanaan terdiri dari tiga sesi yaitu penyajian materi, pembahasan contoh soal dan pengerjaan soal latihan dilanjutkan presentasi jawaban soal latihan. Hasil kegiatan pendampingan ini sudah baik. Terlihat dari antusiasme peserta dalam mengikuti kegiatan dari awal sampai akhir yaitu selalu aktif berdiskusi. Serta pemahaman yang baik dari peserta, terlihat dari kemampuan peserta dalam menyelesaikan soal latihan yang cukup bervariasi serta membutuhkan penalaran yang tinggi.
\end{abstract}

Kata Kunci: Pendampingan, OSN, Matematika, SMP

\begin{abstract}
The OSN event is an annual activity organized by the Directorate of High School Development, Directorate of Primary and Secondary Education, Ministry of Education and Culture, which is a competition that is of particular concern from the school. In this event, schools will send their best students especially in the field of science. The aim of this mentoring activity is to provide material for OSN Mathematics needs for coaches of OSN Mathematics. By this mentoring, mentor of OSN Mathematics can assisting and fostering their students optimally. The method of this activity is carried out through several stages including, the initial stage, the preparation stage and the implementation phase. The initial stage is needs analysis, preparation stage is preparation of instruments while the implementation phase consists of three sessions, namely the presentation of material, discussion of example and do the test followed by presentation. The results of this mentoring activity are good. It can be seen from the enthusiasm of the participants in participating in the activities from the beginning to the end, that is, they are always actively discussing. As well as a good understanding of the participants, it can be seen from the participants' ability to solve the test that are quite varied and require high reasoning.
\end{abstract}

Keywords: Mentoring, OSN, Mathematics, SMP

\section{PENDAHULUAN}

Kegiatan Olimpiade Sains Nasional atau OSN merupakan kegiatan tahunan yang diselenggarakan oleh Direktorat Pembinaan SMA, Direktorat Pendidikan Dasar dan Menengah, Kementrian Pendidikan dan Kebudayaan. Kegiatan OSN mencakup sembilan bidang keilmuan yaitu Matematika, Fisika, Kimia, Informatika/Komputer, Biologi, Astronomi, Ekonomi, Kebumian dan Geografi (Kemendikbud, 2018a).

Kementrian Pendidikan dan Kebudayaan (2018a) menyatakan bahwa OSN memiliki beberapa tujuan khusus, diantaranya menyelenggarakan seleksi secara berjenjang bagi peserta OSN dimulai 
dari tingkat sekolah, tingkat kabupaten/kota, tingkat provinsi, dan tingkat nasional (OSN). Menyeleksi siswa yang mempunyai kompetensi/kemampuan dalam bidangnya masing-masing, yaitu bidang Matematika, Fisika, Kimia, Informatika/ Komputer, Biologi, Astronomi, Ekonomi, Kebumian, dan Geografi. Menyiapkan calon peserta yang dapat diandalkan untuk mewakili Indonesia untuk Olimpiade Tingkat Internasional.

Adapun rangkaian dari OSN sendiri dimulai dari Olimpiade Sains Sekolah (OSS). Selanjutnya peserta yang lolos pada OSS, akan menjadi perwakilan pada Olimpiade Sains Kabupaten/Kota (OSK). Peserta terpilih dari OSK akan mengikuti olimpiade pada level selanjutnya yaitu Olimpiade Sains Provinsi (OSP). Begitu seterusnya, pemenang dari OSP akan mewakili provinsi masing-masing untuk mengikuti Olimpiade Sains Nasional (OSN). Puncaknya peserta terbaik dari OSN akan mengikuti ajang kompetisi tingkat internasional.

Serangkaian kegiatan OSN tersebut tentunya menjadi satu perhatian khusus dari sekolah. Dimana sekolah-sekolah akan mengirimkan peserta didik terbaiknya khususnya dalam bidang sains. Hal ini tentunya memotivasi sekolah untuk meningkatkan kemampuan siswa dalam dalam bidang sains (Antonius Rachmat Chrismanto, Katon Wijana, Rosa Delima, Yuan Lukito, 2018). Salah satu upaya yang dilakukan adalah mempersiapkan peserta didik agar optimal dalam mengikuti OSN serta mendapatkan hasil yang memuaskan (Susanto, Sembiring, \& Ekowati, 2016).

Dalam menjalankan upaya persiapan OSN tersebut membutuhkan tenaga pendamping atau pembina. Sebab peran dari pembina OSN disini sangatlah penting. Dimana, bersama-sama dengan pembina OSN, peserta didik mempersiapkan segala sesuatu terkait OSN terutama materi (substansi matematika) kebutuhan OSN. Oleh karena itu, pembina OSN idealnya memahami serta menguasai materi kebutuhan OSN. Dalam rangka menguatkan penguasaan materi kebutuhan OSN Matematika bagi para pembina OSN Matematika, perlu adanya kegiatan pendampingan pembina OSN Matematika. Hal ini agar guru mendapatkan bekal materi secara teori dan eksperimental serta latihan soal sehingga dapat menumbuhkan sikap kreatif, terampil dan kompetitif dari siswa masing-masing.

Program Studi Pendidikan Matematika Fakultas Keguruan dan Ilmu Pendidikan menjalin kerja sama dengan SMP Negeri 1 Jetis Ponorogo, yang merupakan salah satu sekolah rujukan di Kabupaten Ponorogo. Dimana terdapat beberapa sekolah imbas yang berada dibawah koordinasi SMP Negeri 1 Jetis. Dimana SMP Negeri 1 Jetis merupakan salah satu sekolah yang juga turut serta berpartisipasi dalam kegiatan OSN. Persiapan untuk mengikuti OSNpun dilakukan, salah satunya yaitu memberikan penguatan materi kebutuhan OSN Matematika baik untuk SMP Negeri 1 Jetis itu sendiri maupun sekolah imbasnya. Oleh karena itu, dilakukanlah kegiatan pendampingan guru pembina OSN Matematika bagi sekolah rujukan SMP Negeri 1 Jetis beserta sekolah imbasnya. Hal ini bertujuan untuk meningkatkan kesiapan pembina OSN Matematika sehingga mendapatkan hasil yang lebih baik.

\section{METODE}

Kegiatan pendampingan guru pembina OSN Matematika ini dilaksanakan melalui beberapa tahapan. Adapun tahapan yang dilakukan adalah sebagai berikut:

1. Tahap Awal

Pada tahap ini tim pengabdian melakukan koordinasi dengan mitra yaitu perwakilan dari SMP Negeri 1 Jetis terkait kegiatan pendampingan yang akan diselenggarakan. Bersamaan dengan hal tersebut, dilakukan analisis kebutuhan terutama terkait materi kebutuhan OSN. Berdasarkan hasil koordinasi, ada dua materi yang menjadi prioritas dalam kegiatan pendampingan ini yaitu materi geometri dan kombinatorika. Akan tetapi dengan mempertimbangkan waktu pelaksanaan akhirnya diputuskan untuk mengambil materi kombinatorika yang menjadi pokok bahasan pada kegiatan pendampingan.

2. Tahap Persiapan

Setelah mendapatkan keputusan terkait materi yang akan digunakan selanjutnya tim pengabdian menyusun instrumen yang diperlukan pada kegiatan pendampingan. Meliputi rangkuman materi, soal beserta pembahasan serta soal latihan bagi peserta pendampingan.

3. Tahap Pelaksanaan 
Adapun pada tahap pelaksanaan, kegiatan pendampingan dibagi menjadi tiga sesi. Sesi pertama berupa penyampaian materi dari tim pengabdi terkait Kombinatorika baik berupa konsep maupun contoh soal. Sesi kedua diisi dengan membahas soal. Dalam hal ini soal-soal yang digunakan adalah soal-soal OSN Matematika pada tahun-tahun sebelumnya baik tingkat kabupaten, provinsi maupun nasional. Selanjutnya pada sesi ketiga yaitu latihan soal. Peserta pendampingan mengerjakan beberapa soal latihan, kemudian beberapa perwakilan peserta diberikan kesempatan untuk mempresentasikan hasil pekerjaan yang telah diperoleh.

\section{HASIL DAN PEMBAHASAN}

Pelaksanaan kegiatan pendampingan guru pembina OSN ini di SMP Negeri 1 Jetis Kabupaten Ponorogo yang merupakan sekolah rujukan. Hal ini mempermudah peserta pendampingan dari sekolah imbas karena sudah terbiasa mengikuti kegiatan di sekolah rujukannya yaitu SMP Negeri 1 Jetis. Kegiatan pendampingan ini dilakukan selama satu hari bersama dengan tim pengabdian kepada masyarakat yang terdiri dari 3 dosen Program Studi Pendidikan Matematika Fakultas Keguruan dan Ilmu Pendidikan Universitas Muhammadiyah Ponorogo.

Kegiatan pendampingan ini diikuti oleh 15 peserta. Peserta tersebut merupakan guru pembina OSN Matematika baik dari SMP Negeri 1 Jetis sendiri maupun pembina OSN Matematika sekolah imbas dari sekolah rujukan SMP Negeri 1 Jetis. Adapun beberapa sekolah imbas tersebut diantaranya SMP Negeri 1 Ngebel, SMP Negeri 4 Ponorogo, SMP Negeri 1 Sooko, SMP Negeri 1 Ngrayun, serta SMP Negeri 2 Balong.

Melalui kegiatan ini diharapkan peserta mendapatkan pemahaman serta penguatan materi sebagai bahan dalam mendampingi serta membina siswa yang akan mewakili sekolah mengikuti OSN Matematika. Disamping itu, peserta bisa menambah referensi dari berbagai macam variasi soal OSN Matematika baik dari tingkat kabupaten, provinsi maupun nasional berikut pembahasannya. Sehingga diharapkan bisa lebih maksimal ketika membina dan mendampingi siswa siswinya.

Pelaksanaan kegiatan pendampingan ini, diawali dengan penyampaian materi oleh tim pengabdian. Dengan bantuan media power point serta whiteboard tim pengabdian menyajikan konsep materi kombinatorika diikuti contoh-contoh soalnya. Ternyata peserta masih merasa asing dengan istilah kombinatorika. Karena materi ini memang bukanlah materi yang secara keseluruhan diajarkan pada tingkat SMP. Namun baru sebagian saja yang dipelajari dan dikenal dengan istilah Kaidah Pencacahan yang meliputi Aturan Perkalian, Aturan Penjumlahan, Permutasi serta Kombinasi. Para peserta tentunya lebih familiar dengan istilah-istilah tersebut. Pada kegiatan pendampingan ini, konsep materi kombinatorika yang disampaikan adalah Kaidah Pencacahan yang meliputi 4 pokok bahasan seperti yang telah disebutkan sebelumnya. Ditambah dengan materi permutasi berulang yang tidak lain adalah gabungan dari materi permutasi dan kombinasi. Setiap pokok bahasan yang disampaikan diikuti contoh soal agar membantu peserta dalam memahami materi yang disampaikan. Peserta pendampingan ini tampak antusias dalam mengikuti, hal ini dapat dilihat dari respon peserta pada saat kegiatan penyampaian materi berlangsung.

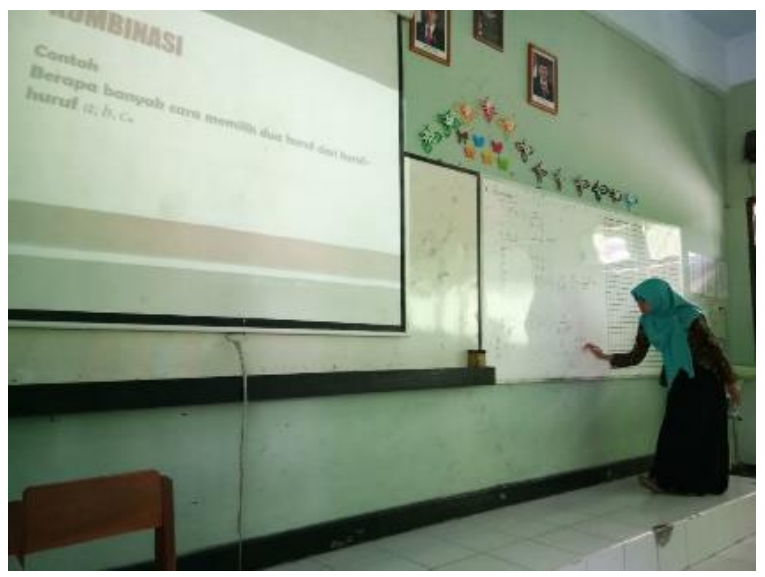

Gambar 1. Penyajian konsep materi 
Setelah sesi penyampaian materi selesai, dilanjutkan dengan sesi pembahasan soal. Disini peserta pendampingan mencoba menyelesaikan beberapa contoh soal dan dipandu oleh tim pengabdian. Contoh soal yang diberikan pada sesi ini levelnya lebih sulit dibandingkan dengan contoh soal yang disampaikan pada sesi 1 . Contoh soal yang dibahas pada sesi ini merupakan soal OSN Matematika pada tahun-tahun sebelumnya, baik tingkat kabupaten, provinsi maupun nasional. Tentunya soal-soal tersebut cukup bervariasi serta memerlukan penalaran yang tinggi. Karena pada hakikatnya soal-soal OSN merupakan soal yang membutuhkan ketrampilan berpikir tingkat tinggi (High Order Thinking Skill atau HOTS) (Kemendikbud, 2018b). Dalam pembahasan contoh latihan soal ini, peserta antusias mencoba mengerjakan terlebih dahulu sebelum dibahas bersama-sama dengan tim pengabdian.

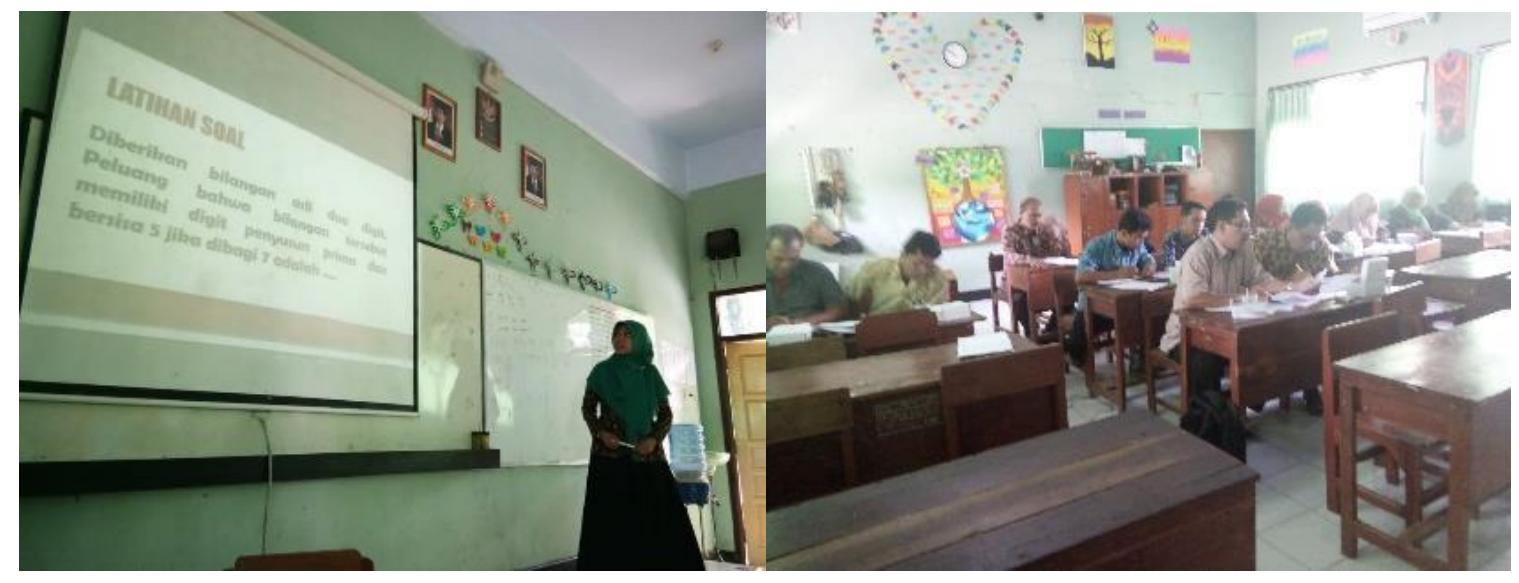

Gambar 2. Pemberian dan pembahasan latihan soal

Beberapa peserta berdiskusi dalam mencoba menyelesaikan contoh soal yang diberikan. Pada sesi ini tampaknya dalam menyelesaikan contoh soal yang diberikan, peserta perlu dibantu dalam memunculkan ide pengerjaannya. Sehingga tim pengabdian mengarahkan peserta terkait ide yang digunakan dalam menyelesaikan soal yang dimaksud. Setelah peserta sudah mulai terbiasa dengan beberapa jenis soal kombinatorika, kegiatan pendampingan dilanjutkan pada sesi yang terakhir.

Sesi terakhir dari kegiatan pendampingan ini adalah latihan soal yang selanjutnya dipresentasikan di depan kelas. Pada sesi ini tim pengabdian membagikan lembar soal latihan yang terdiri dari 3 soal kombinatorika. Dimana soal tersebut juga merupakan soal OSN Matematika pada tahun-tahun sebelumnya. Dalam mengerjakan soal latihan ini, peserta diperbolehkan berdiskusi satu sama lain. Akan tetapi tanpa dipandu oleh tim pendampingan dalam memunculkan ide pengerjaan. Hal ini dilakukan sebagai evaluasi atas pemberian materi serta contoh soal yang telah dilakukan pada sesi 1 dan sesi 2 .

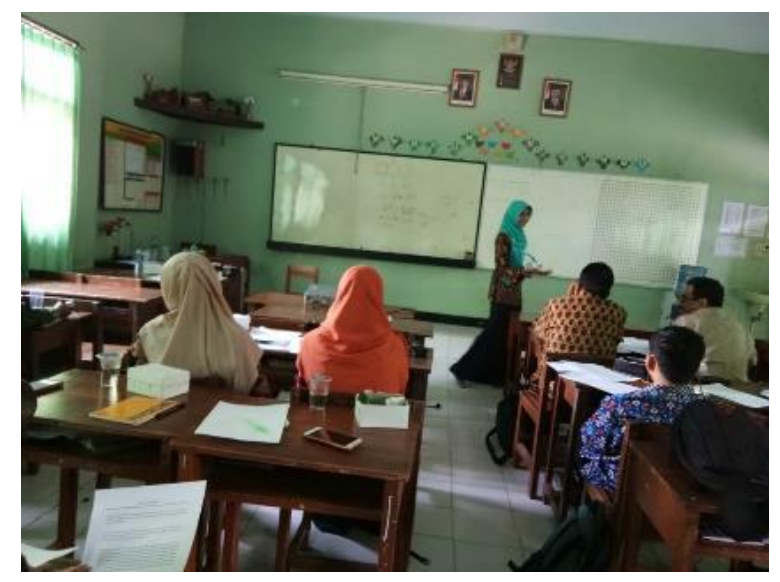

Gambar 3. Pembagian soal latihan 
Tim pengabdian memberikan waktu sekitar 45 menit kepada peserta untuk menyelesaikan soal latihan yang ada. Sama seperti pada sesi 2, diskusi kembali terjadi pada sesi 3 ini. Peserta saling bertukar pendapat terkait ide awal dalam menyelesaikan soal yang diberikan.

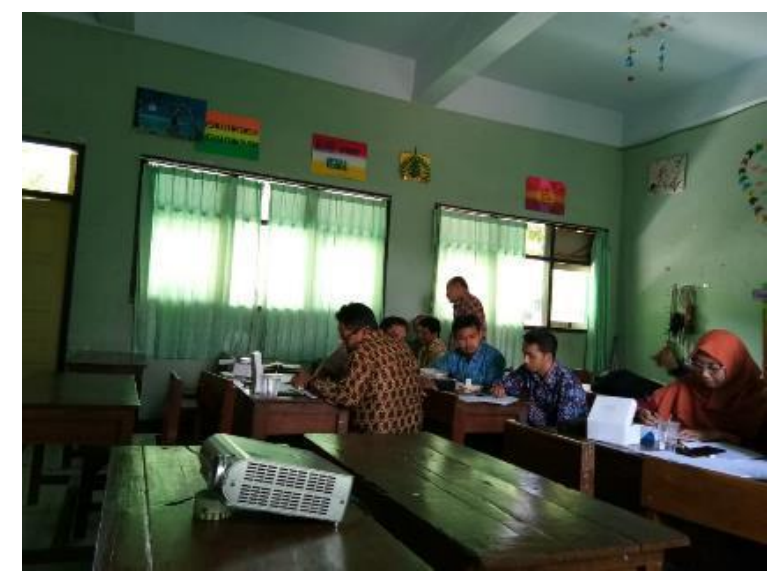

Gambar 4. Para peserta menyelesaikan soal latihan

Setelah selesai mengerjakan, beberapa peserta mempresentasikan hasil penyelesaian yang telah diperoleh. Adapun peserta yang lain ikut serta menanggapi apa yang telah disampaikan peserta di depan kelas. Soal latihan yang diberikan pada sesi terakhir terselesaikan semua dengan jawaban yang benar.

Dilihat dari penyelesaian soal yang diperoleh peserta, nampaknya peserta telah memahami materi kombinatorika dengan baik. Meskipun soal yang diberikan sebagai latihan pada sesi tiga ini cukup bervariasi, peserta telah berhasil menyelesaikannya dengan baik. Peserta mampu mendapatkan ide awal penyelesaian soal dan selanjutnya mampu mengeksekusi ide tersebut dengan baik. Sehingga diperoleh jawaban yang benar.

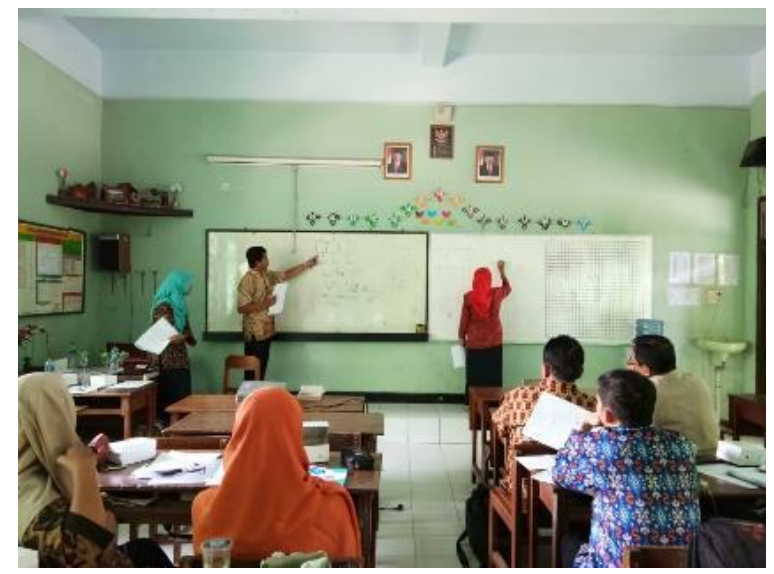

Gambar 5. Presentasi hasil pekerjaan

Berdasarkan uraian diatas, dapat diketahui bahwa melalui pemberian latihan soal yang cukup bervariasi serta dalam jumlah yang banyak, mampu membantu pemahaman peserta terkait materi yang telah diberikan. Hal tersebut dapat dilihat pada saat peserta mampu menyelesaikan soal dengan tepat. Hal ini sejalan dengan hasil penelitian yang dilakukan oleh Ningsih, bahwa metode latihan (drill) mampu meningkatkan pemahaman matematika (Ningsih, 2016). Dengan hasil ini, diharapkan mampu meningkatkan kualitas pembimbingan OSN Matematika di sekolah masing-masing peserta. 


\section{SIMPULAN}

Kegiatan pendampingan guru OSN Matematika di SMP Negeri 1 Jetis ini telah berjalan dengan maksimal. Kegiatan pendampingan ini menunjukkan hasil yang baik. Terlihat dari antusiasme peserta dalam mengikuti kegiatan dari awal sampai akhir yaitu selalu aktif berdiskusi. Serta pemahaman yang baik dari peserta, terlihat dari kemampuan peserta dalam menyelesaikan soal latihan yang cukup bervariasi serta membutuhkan penalaran yang tinggi.

\section{SARAN}

Adapun saran bagi kegiatan pengabdian selanjutnya adalah terkait alokasi waktu. Untuk kegiatan serupa, akan lebih maksimal jika alokasi waktu yang diberikan lebih lama. Akan lebih baik ketika kegiatan seperti ini dilakukan secara berkesinambungan.

\section{UCAPAN TERIMA KASIH}

Penulis mengucapkan terima kasih kepada SMP Negeri 1 Jetis Ponorogo yang telah memfasilitasi kegiatan pengabdian ini.

\section{DAFTAR PUSTAKA}

Antonius Rachmat Chrismanto, Katon Wijana, Rosa Delima, Yuan Lukito, H. B. S. (2018). Analisis Perbandingan Model Program Pendampingan untuk Pelatihan OSN Komputer Siswa SMA (pp. 79-87). Seminar Nasional Hasil Pengabdian Kepada Masyarakat.

Kemendikbud. (2018a). Panduan Pelaksanaan Olimpiade Sains Nasional.

Kemendikbud. (2018b). Silabus OSN Tingkat SMP 2018.

Ningsih, R. E. . (2016). Penerapan Metode Drill untuk Meningkatkan Pemahaman Matematika Siswa Kelas VIII SMP Negeri 5 Tanjung Morawa. School Education Journal PGSD FIP UNIMED, 6(2), 72-78.

Susanto, G. N., Sembiring, S., \& Ekowati, C. N. (2016). PEMBINAAN GURU SEBAGAI DASAR PENINGKATAN PRESTASI SISWA SD DALAM AJANG KOMPETISI OSN SD IPA TINGKAT NASIONAL. In PROSIDING SEMINAR NASIONAL HASIL-HASIL PENGABDIAN KEPADA MASYARAKAT UNIVERSITAS LAMPUNG 2016 (p. 1120123). Bandar Lampung: LEMBAGA PENELITIAN DAN PENGABDIAN KEPADA MASYARAKAT UNIVERSITAS LAMPUNG. 